\title{
UJI AKTIVITAS MUKOLITTIK EKSTRAK ETANOL DAUN TALAS SENTHE (Alocasia macrorrhiza (L) schott)
}

\author{
Shafira Anjelia ${ }^{* 1}$,Slamet ${ }^{2}$, Wirasti ${ }^{3}$, Dwi Bagus Pambudi ${ }^{4}$ \\ ${ }^{*}{ }^{*}, 2,3$ Universitas Muhammadiyah Pekajangan Pekalongan, Pekalongan, Jawa Tengah, Indonesia \\ e-mail: ${ }^{* 1}$ shafiraanjelia9@gmail.com, ${ }^{2}$ slamet93ffua@gmail.com, ${ }^{3}$ wirasti.kharis@gmail.com. \\ ㄹwibagus589@gmail.com
}

\begin{abstract}
ABSTRAK
Talas Senthe (Alocasia Macrorrhiza (L) Schott) secara tradisional telah digunakan masyarakat Indonesia sebagai pengencer dahak untuk membantu mengobati batuk. Penelitian ini bertujuan untuk mengetahui aktivitas mukolitik ekstrak etanol daun talas senthe dengan beberapa konsentrasi ekstrak. Ekstrak etanol diperoleh dengan menggunakan metode maserasi dan uji aktivitas mukolitik dari ekstrak dilakukan secara in vitro terhadap penurunan viskositas dari ekstrak etanol daun talas senthe terhadap mukosa usus sapi dengan menggunakan viskometer. Larutan uji dibuat dengan menggunakan konsentrasi ekstrak 0,1\%; 0,5\%; 1\%; 1,5\%; 1,75\% dan 2\% dicampur dengan larutan mukus dapar fosfat pH 7. Asetilsistein 0,1\% digunakan sebagai kongtrol positif sedangkan mukus tanpa ekstrak digunakan sebagai kontrol negatif. Aktivitas mukolitik ditunjukan dengan penurunan viskositas larutan mukus. Data yang diperoleh dianalisis statistik menggunakan uji Kruskall-Wallis untuk mengetahui perbedaan antar kelompok perlakuan. Hasil penelitian ini menunjukan bahwa ekstrak etanol daun talas senthe pada konsentrasi 1\%, 1,5\% dan 2\% memberikan efek mukolitik yang sebanding dengan obat asetilsistein 0,1\% sebagi pengancar dahak.
\end{abstract}

Kata kunci : Talas Senthe, Ekstrak, Mukolitik, Penurunan viskositas mukus

\begin{abstract}
Taro Senthe (Alocasia Macrorrhiza (L) Schott) has traditionally been used by Indonesian people to help treat coughs. This study aims to determine the mucolytic activity of the ethanol extract of senthe taro leaves in vitro with several extract concentrations. The ethanol extract was obtained using maceration method and the mucolytic activity test of the extract was carried out in vitro to decrease the viscosity of the ethanol extract of senthe taro leaves on the intestinal mucosa of cattle using a viscometer. The test solution was prepared with an extract concentration of $0.1 \% ; 0.5 \% ; 1 \% ; 1.5 \% ; 1.75 \%$ and $2 \%$ were mixed with a mucusphosphate buffer solution pH 7. Acetylcysteine $0.1 \%$ was used as a positive control. Mucus solution without extract was used as a negative control. Mucolytic activity was indicated by a decrease in the viscosity of the mucus solution. The data obtained were statistically analyzed using the ANOVA test with a 95\% confidence level to determine differences between treatment groups. The results of this study showed that the ethanolic extract of senthe taro leaves at concentrations of 1\%, 1,5\% and $2 \%$ gave a mucolytic effect comparable to $0.1 \%$ acetylcysteine as a phlegm carrier.
\end{abstract}

Keywords : Taro Senthe, Extract, Mucolytic, Decreased mucus viscosity

\section{PENDAHULUAN}

Masyarakat Indonesia sejak jaman dahulu mengenal dan memakai tanaman berkhasiat obat sebagai salah satu upaya penanggulangan masalah kesehatan jauh sebelum pelayanan kesehatandan obat-obat modern dikenal oleh masyarakat seperti sekarang. Pengetahuan tentang obat ini merupakan warisan budaya bangsa berdasarkan pengalaman yang secara turun menurun telah diwariskan oleh generasi terdahulu kepada generasi saat ini [1]. 
Pengobatan tradisional merupakan salah satu bentuk peran serta masyarakat dan sekaligus merupakan teknologi potensial yang tepat guna untuk menunjang pembangunan kesehatan. Pada umumnya, yang dimaksud dengan obat-obatan tradisional adalah ramuan dari tumbuhan berkhasiat obat yang telah dipergunakan secara turun temurun. Penggunaan obat tradisional dipercaya dapat mengobati berbagai macam penyakit dan memiliki efek samping relatif lebih kecil dibandingkan obta odern.

Pemanfaatan tumbuhan untuk mengobati berbagai macam penyakit kembali banyak digemari oleh masyarakat, karena dinilai lebih aman, ekonomis, dan memiliki efek samping yang lebih sedikit daripada menggunakan obat sintesis. Penggunaan berbagai jenis tumbuhan untuk pengobatan, dilakukan pada penyakit yang bersifat ringan maupun pada penyakit yang bersifat berat.

Tumbuhan yang digunakan untuk pengobatan, dapat berasal dari tumbuhan yang telah terbukti memiliki khasiat untuk kesehatan, misal jahe, kunyit, habatusauda dan lain sebagainya. Selain dari tumbuhan yang telah terbukti memiliki khasiat untuk kesehatan, banyak masyarakat yang melakukan pengobatan menggunakan tumbuhan yang belum dikenal memiliki khasiat untuk kesehatan, dan pengobatan didasarkan pada khasiat empiris misal pengobatan batuk mengunakan tanaman sente.

Batuk adalah pertahanan alami tubuh ketika saluran pernapasan diserang oleh partikel asing maupun agen penyebab infeksi. Terapi simtomatik batuk, terutama batuk berdahak adalah dengan menggunakan mukolitik. Upaya pengobatan batuk menggunakan obat mukolitik yang banyak digunakan adalah obat-obat yang berasal dari obat sintetik seperti ambroxol, asetilsistein, dll yang sudah terbukti memiliki efek dapat mengencerkan dahak. Namun, penggunaan obat sintetik diketahui dapat menimbulkan efek samping yang merugikan bagi manusia seperti urtikaria, bronkopasme, reaksi alergi dll [2]. Oleh karena itu, maka dilakukan alternatif lain yaitu dengan memanfaatkan suatu tanaman sebagai pengobatan batuk. Tumbuhan Talas Sente (Alocasia Macrorrhiza (L) Schott) merupakan bahan alam yang dipercaya secara empiris dapat membantu menyembuhkan batuk berdahak.

Di Indonesia tanaman senthe (Alocasia Macrorrhiza (L) Schott) selama ini dikenal masyarakat sebagai sayur-sayuran yang biasa dikonsumsi sehari-hari. Daun talas senthe merupakan salah satu diantara sekian banyak tumbuhan obat yang digunakan sebagai obat batuk oleh masyarakat. Salah satu mekanisme pengobatan batuk dengan mukolitika. Selain dipercaya dapat menyembuhkan batuk, Tanaman Talas Sente (Alocasia Macrorrhiza (L) Schott) digunakan oleh masyarakat untuk menyembuhkan radang tenggorokan. Penelitian lain juga menyebutkan bahwa Tanaman Talas Senthe (Alocasia Macrorrhiza (L) Schott) berfungsi sebagai antitumor, antifungal, dan antioksidan [3].

Sejalan dengan perkembangan ilmu pengetahuan dan teknologi, manusia ingin memanfaatkan tanaman senthe sebagai hasil alam untuk menjadi bahan yang mempunyai nilai ekonomi tinggi dan dapat berkhasiat sebagai obat batuk. Talas Sente (Alocasia Macrorrhiza (L) Schott) memiliki Kandungan kimia yang terdiri Flavonoid, Polifenol, dan Saponin [4].

Pemanfaatan Talas Sente (Alocasia Macrorrhiza (L) Schott) sebagai tanaman yang secara empiris dipercaya dapat mengobati batuk dengan cara mengencerkan dahak, dengan adanya dugaan ini perlu dilakukan penelitian yang bersifat ilmiah dalam hal ini untuk menguji aktivitas 
mukolitiknya sehingga nantinya dapat dibuktikan keamanan dan manfaatnya sebagai obat batuk yang murah dan dapat digunakan. Dan hal ini memberikan inspirasi kepada penulis, untuk melakukan penelitian Uji Aktivitas Mukolitik Ekstrak Etanol Daun Talas Sente (Alocasia Macrorrhiza (L) Schott) Secara In Vitro.

\subsection{Alat dan Bahan}

\section{METODE PENELITIAN}

Penelitian ini menggunakan alat-alat berupa maserator,viskometer Digital, neraca (OhausAR 3130), thermostatic waterbath (Memmert), dan pHmeter (Hanna HI 8014), rotator evaporator, oven, ayakan mesh No. 40, penyaring, Erlenmeyer, tabung reaksi, batang pengaduk, gelas beaker, labu ukur, magnetic stirer, dan cawan.

Bahan-bahan yang digunakan adalah daun talas senthe, etanol 96\% (Brataco),mukus usus sapi, dapar fosfat $\mathrm{pH} \mathrm{7,} \mathrm{asetilsistein} \mathrm{murni,} \mathrm{kloroform,} \mathrm{ammonia,} \mathrm{asam} \mathrm{sulfat} \mathrm{pekat,} \mathrm{pereaksi}$ Mayer dan Dragondorf, magnesium, besi (III) klorida, HCL, asam asetat anhidrat, kalium dihirogenfosfat, air bebas $\mathrm{CO}$, natrium hidroksida 0,2 N, tween 80 dan Aquadest.

\subsection{Jalannya Penelitian}

Desain penelitian ini adalah penelitian eksperimental yang digunakan untuk pengujian aktivitas mukolitik ekstrak etanol daun Talas Senthe (Alocasia macrorrhiza $(L)$ Schott). Penelitian dilakukan secara in vitro menggunakan usus sapi untuk mengetahui efektivitas mukolitik tanaman Talas Senthe (Alocasia macrorrhiza (L) Schott) yang digunakan sebagi pengobatan batuk berdahak.Usus sapi yang telah diperoleh dibersihkan dari kotoran dengan air mengalir. Pengumpulan mukus dilakukan dengan memotong usus secara membujur lalu mukus dikerok menggunakan sendok secara perlahan. Mukus yang telah terkumpul diaduk sampai homogen. Bagaian usus yang digunakan pada penelitian adalah usus besar, usus dari hewan mempunyai dua kelenjar yang penting yaitu kelenjar intestinal dan duodenal. Kelenjer intestinal, berbentuk tubular sederhana yang terdapat disepnajang usus besar maupun usus kecil. Sel-sel yang menyelaputi bersifat kontinyu dan berbuhungan dngan sel epitel yang menutup membran mukosa. Sekresi oleh kelenjer tersebut disebut cairan intestinal atau sukus enterikus [5]. Mukus yang digunakan untuk uji harus dalam kondisi yang masih segar, kemudian disimpan dalam lemari es pada suhu kurang dari $4^{\circ} \mathrm{C}[6]$.

Uji aktivitas mukolitik dilakukan dengan melakukan pengukuran viskositas menggunakan viskometer brookfield. Sampel uji diinkubasi pada suhu $37^{\circ} \mathrm{C}$ selama 30 menit kemudian dipipet larutan uji dan dimsukkan kedalam tempat sampel dalam viskometer digital. Lalu dipasang spindle no. 40 pada gantungan spindel. Setelah itu, diturunkan spindle hingga tanda batas tercelup kedalam larutan uji dan diatur kecepatan putaran 20 rpm dilakukan pengulangan sebanyak 3 kali.

\subsection{Analisis Data}

Penelitian ini bersifat eksperimental laboratorium. Analisis data dilihat dengan ada tidaknya perbedaan bermakna pada nilai viskositas mukus sapi antara kelompok kontrol positif, kontrol negatif dan kelompok uji aktivitas ekstrak etanol daun talas senthe. Data tersebut dianalisis dengan uji statistik menggunakan uji Kruskal-Wallis untuk membandingkan nilai ratarata dari masing-masing kelompok perlakuan yang berbeda signifikan, dikatakan beda signifikan apabila $<0,05$ dan tidak beda signifikakn apabila $>0,05$. Analisis statistic ini akan dilakukan dengan bantuan program computer. Analisis dilanjutkan dengan uji in vitro dengan model kompartemen satu terbuka. 


\section{HASIL DAN PEMBAHASAN}

\subsection{Pengambilan Sampel}

Bagian tumbuhan Talas Senthe yang digunakan sebagai bahan penelitian ini adalah daun Talas Senthe yang memiliki tangkai berwarna hijau yang biasa disebut Talas Senthe hijau. Talas senthe yang digunakan untuk penelitian ini diperoleh di Desa Trajumas, Dusun Mekarmas, Kecamatan Kandangserang, Kabupaten Pekalongan. Pengambilan daun Talas Senthe sebagai bahan utama dilakukan pada satu waktu yaitu bulan Juli 2021. Hal ini dimaksudkan untuk menghindari adanya variasi kandungan kimia yang besar yang disebabkan perbedaan kondisi lingkungan dan iklim.

Daun talas senthe dipilih yang baik, kemudian dibersihkan dari kotoran-kotoran yang melekat seperti debu, telur-telur cacing dan lain-lain dengan cara dicuci dibawah air mengalir. Kemudian dirajang untuk memudahkan pada saat pengeringan. Kemudian irisan daun talas senthe tersebut dikeringkan dalam almari pengering pada suhu $60^{\circ} \mathrm{C}$ selama 3 hari.Irisan daun talas senthe yang telah kering kemudian dilakukan sortasi kering dan dihaluskan dengan blender pada kecepatan tinggi dan diayak menggunakan ayakan 40 mesh sehingga diperoleh serbuk daun talas senthe dengan derajat halus tertentu.Ayakan 40 mesh yaitu ayakan yang dimana setiap 1 inc terdapat 40 lubang. Dari daun talas senthe segar sebanyak $8 \mathrm{~kg}$ menghasilkan $691 \mathrm{~g}$ serbuk kering yang selanjutnya dikemas dan diberi etiket sebagai identitas. Hasil pembuatan simplisia tertera pada lampiran 6 hal 80 .

\subsection{Maserasi}

Maserasi dilakukan dengan merendam serbuk hasil pemblenderan sebanyak 691 gram dalam cairan penyari yaitu etanol $96 \%$ sebanyak 4 L. Proses maserasi dilakukan dalam wadah berukuran sedang yang ditutup dengan kain gelap selama 5 hari dan selama perendaman diaduk satu kali sehari selama satu jam,Setelah diserkai dan disaring menggunakan kain flannel kemudian diperas untuk mempercepat proses pemisahan ampas dan filtrat. sedangkan ampas yang didapat direndam kembali dengan etanol 96\% sebanyak 2 L selama 2 hari sambil diaduk satu kali sehari selama satu jam.Pada remaserasi didapatkan filtar kemudian diuapkan menggunakan rotary evaporator pada suhu $60^{\circ} \mathrm{C}$ agar senyawa yang terdapat pada simplisia tidak rusak. Selanjutnya ekstrak cair diuapkan dengan menggunakan oven pada suhu $60^{\circ} \mathrm{C}$ sehingga didapatkan ekstrak kental berwarna coklat, pada penelitian didapatkan ekstrak kental sebanyak 70 g.Hasil randemen ekstrak daun talas senthe (Alocasia Macrorrhiza (L) Schott) pada penelitian ini adalah $10,13 \%$.

\subsection{Penetapan Kadar Air}

Kelebihan kadar air dapat menjadi media tumbuh dan berkembangnya jamur. Hasil uji parameter non spesifik ekstrak daun talas senthe (Alocasia Macrorrhiza (L) Schott) menunjukan kadar air yang memenuhi persyaratan yaitu kurang dari 10\%. Menurut Depkes RI Tahun 2008 [7] kadar air yang aman untuk ekstrak tidak lebih dari 10\%. Kadar air yang tinggi dapat mempengaruhi stabilitas ekstrak serta rentan terhadap pertumbuhan baketri dan fungi [8].

\subsection{Skrinning Fitokimia}

Skrining fitokimia merupakan tahap awal untuk mengetahui kandungan senyawa aktif yang ada di dalam ekstrak dengan menggunakan pereaksi kimia sehingga terbentuk suatu reaksi warna. Uji fitokimia yang dilakukan yaitu uji flavanoid, saponin, tanin dan alkaloid. Berdasarkan hasil uji skrining fitokimia pada tabel I menunjukan bahwa ekstrak daun talas senthe (Alocasia Macrorrhiza (L) Schott) positif mengandung senyawa saponin, alkaloid, dan flavonoid. Sedangkan hasil uji diperoleh hasil negatif mengandung senyawa tanin. Berdasarkan hasil uji skrining fitokimia menunjukan bahwa ekstrak daun talas senthe (Alocasia Macrorrhiza (L) Schott) positif mengandung senyawa saponin, alkaloid, dan flavonoid. Sedangkan hasil uji diperoleh hasil negatif mengandung senyawa tanin. Ekstrak daun talas senthe menunjukan hasil 
positif dengan penambahan etanol dan $\mathrm{HCl}$ kerana menghasilkan larutan berwarna merah kecoklatan. Hal tersebut menunjukan bahwa ekstrak tanol daun talas senthe mengandung senyawa golongan flavanoid. Kompleks berwarna merah kecoklatan dihasilkan dari ikatan kovalen koordinasi antara ion magnesium dengan gugus $\mathrm{OH}$ fenolik senyawa flavanoid.

Pada uji alkaloid dengan pereaksi mayer diperkirakan nitrogen pada alkaloid akan bereaksi dengan ion logam $\mathrm{K}+$ dari kalium tetraiodomerkurat (II) yang selanjutnya membentuk kompleks kalium-alkoloid yang mengendap. Prinsip dari metode analisis ini adalah terjadinya reaksi pengendapan yang terjadi karena penggantian ligan. Atom nitrogen yang mempunyai pasangan elektron bebas pada alkoloid dapat mengganti ion iodo dan kalium iodida.Pada reaksi menggunakan reagen Dreagendorf, ion logam $\mathrm{K}+$ membentuk ikatan kovalen koordinasi dengan alkoloid sehingga terbentuk kompleks kalium-alkaloid yang mengendap.Pada pengujian senyawa saponin diperoleh hasil positif dengan terbentuknya buih atau busa stabil selama 10 menit. Busa yang timbul pada uji saponin ini menunjukan adanya glikosida saponin yang mempunyai kemampuan membentuk buih dalam air yang terhidrolisis menjadi glukosa dan senyawa lain, hal ini juga sebagai gugus polar dan gugus terpenoid/steroid sebagai gugus non polar. Senayawa yang memiliki gugus polar dan non polar bersifat aktif sehingga saat dikocok dengan air, saponin dapat membentuk misel. Pada struktur misel, gugus polar menghadap keluar sedangkan gugus non polarnya menghadap kedalam.

Pada penguji senyawa tanin diperoleh hasil negatif dengan terbentuk warna merah coklat. Hal tersebut karena tidak adanya reaksi reduksi dari $\mathrm{FeCl}_{3}$ dengan gugus fenol dan tanin. Hasil reaksi tersebut yang akhirnya kompleks warna. Pereaksi $\mathrm{FeCl}_{3}$ digunakan secara luas untuk mengidentifikasi senyawa fenol yaitu senyawa tanin. Dari uji skrining fitokimia yang dilakukan diperoleh hasil sebagai berikut :

Tabel I. Hasil Uji Skrining Fitokimia Ekstrak Daun Talas Senthe (Alocasia Macrorrhiza

\begin{tabular}{l|c}
\multicolumn{2}{c}{$($ L) Schott $)$} \\
\hline Metabolit Sekunder & Hasil \\
\hline Flavanoid & ++ \\
Saponin & ++ \\
Tanin & - \\
Alkaloid & ++ \\
\hline
\end{tabular}

\subsection{Uji Aktivitas Mukolitik}

Setelah didapat ekstrak kental sebagai larutan uji dengan kadar yang telah ditentukan kemudian diuji aktivitas mukolitiknya yaitu dengan melihat kemampuannya dalam mengencerkan mukus sehingga menurunkan viskositasnya.Mukus didapat dengan cara membelah usus secara membujur kemudian dikerok usus sapi yang sebelumnya telah dibersihkan dari kotoran dan sisa makanan dengan air mengalir. Dalam peneltian ini usus yang digunakan adalah usus besar dan usus kecil, namun usus yang kecil lebih sedikit mengahsilkan lendir. Mukus yang diperoleh kental dan berwarna putih kecoklatan. Karena kekentalam mukus yang didapat berbedea-beda maka diaduk hingga homogen. Sebelum dilakukan pengujian, mukus disimpan dilemari es pada suhu $4^{\circ} \mathrm{C}$ untuk mencegah terjadinya reaksi enzimatik yang dapat merusak dan merubah konsistensi mukus, misalnya ensim proteolitik yang dapat mengakibatkan mukus menjadi lebih encer dan berair.

Alat yang digunakan pada uji aktivitas mukolitik ini adalah viskometer digital. Sebelum mukus digunakan untuk uji daya mukolitik dilakukan pengenceran dengan larutan dapar fosfat $\mathrm{pH} 7$, hal ini dimaksudkan agar mukus memiliki konsistensi yang lebih rendah. Penggunaan dapar fosfat dimaksudkan agar pada percobaan ini memiliki kesesuaian dengan kondisi fisiologis 
manusia, selain itu karena pada $\mathrm{pH}$ yang lebih asam akan menaikan viskositas mukus, sehingga akan mengurangi sifat alirnya [9].

Pada penentuan viskositas dari campuran larutan antara mukus $20 \%$ dalam dapar fosfat dan larutan uji terlebih dahulu diinkubasi pada suhu $37^{\circ} \mathrm{C}$ selama 30 menit. Hal ini dimaksudkan agar kondisi reaksi antara larutan uji dengan mukus sesuai dengan kondisi fisiologis manusia. Selain itu perubahan temperatur juga dapat mempengaruhi viskositas suatu cairan, karena dengan naiknya temperatur maka viskositas cairan akan menurun. Untuk mencapai keseimbangan termis suautu cairan harus diinkubasi selama 30 menit. Dalam penelitian ini digunakan Viskometer Digital dengan nomor rotor 02 dengan kecepatan $30 \mathrm{rpm}$.

Dari penelitian dapat dilihat bahwa kekentalan mukus setelah pemberian ekstrak daun talas senthe dengan berbagai konsentrasi menunjukan adanya penurunan bila dibandingkan dengan kontrol negatif. Hal ini berarti bahwa mulai pada konsentrasi $0,1 \%$ ekstrak etanol daun talas senthe menunjukan adanya daya mukolitik. Pada konsentrasi ini daya mukolitiknya dalah yang paling terkecil sehingga apabila dibandingkan akan menjadi sangat signifikan. Pada konsentrasi $1,5 \%, 1,75 \%$, dan $2 \%$ daya mukolitik yang dimilikinya dalah yang paling terbesar, bahkan lebih besar bila dibandingkan dengan kontrol positif hal ini disebabkan karena pada konsentrasi ekstrak yang besar komponen makromolekul juga maikn besar. Hal ini berarti ekstrak etanol daun talas senthe pada konsentrasi $1,5 \%, 1,75 \%$ dan $2 \%$ memiliki daya mukolitik yang setara dengan larutan asetilsistein $0,1 \%$ yang telah terbukti memiliki daya mukolitik yang dapat digunakan sebagai pengencer dahak. Digunakan asetilsistein sebagai kontrol positif karena selain telah terbukti memiliki daya mukolitik sehingga dahak lebih mudah dikeluarkan melalui batuk.

Aktivitas mukolitik dari tanaman talas senthe diketahui dari kandungan senyawa metabolisme sekunder yang terkandung dalam daun talas senthe, yaitu alkaloid, flavanoid dan saponin. Saponin bekerja dengan cara merangsang keluarnya secret daribronkial. Saponin bekerja dengan cara meningkatkan aktivasi epitel silia, suatuperistiwa yang membangkitkan batuk sehingga dapat mengeluarkan daha. Sedangkan alkaloid berfungsi untuk menganggu komponen penyusunpeptidoglikan pada sel bakteri, sehingga lapisan sel bakteri tidakterbentuk. Flavonid bekerja dengan cara memecahkan benang-benag mukoprotein dan mukopolisakarida dari mukus. Untuk melihat besar daya mukoliik yang dimiliki masing-maisng konsentrasi ekstral etanol daun talas senthe dilakukan uji statistik anova satu arah membandingkan dengan kontrol positif yaitu larutan asetilsistein $0,1 \%$.

Tabel II. Hasil uji aktivitas mukolitik dengan Viskometer Digital

\begin{tabular}{ccccc}
\hline No & Kadar ekstrak & \multicolumn{3}{c}{ Viskositas (cp) } \\
\cline { 3 - 5 } & & $\mathbf{X}_{\mathbf{1}}$ & $\mathbf{X}_{\mathbf{2}}$ & $\mathbf{X}_{\mathbf{3}}$ \\
\hline 1 & Kontrol Negatif & 943 & 942 & 945 \\
2 & Kontrol Positif & 867 & 866 & 867 \\
3 & $0.1 \%$ & 914 & 912 & 913 \\
4 & $0.5 \%$ & 879 & 881 & 871 \\
5 & $1 \%$ & 865 & 860 & 863 \\
6 & $1.5 \%$ & 864 & 863 & 864 \\
7 & $1.75 \%$ & 795 & 800 & 818 \\
8 & $2 \%$ & 785 & 779 & 808 \\
\hline
\end{tabular}

Keterangan tabel : $\mathrm{X}_{1}$ : Viskositas replikasi pertama (cp), $\mathrm{X}_{2}:$ Viskositas replikasi kedua (cp), $\mathrm{X}_{3}$ : Viskositas replikasi ketiga (cp), cp : Satuan viskositas (centripois) 


\subsection{Uji Kolmogrov-Smirnov Test}

Uji normalitas digunakan untuk mengetahui apakah asumsi bahwa beberapa kelompok sampel yang ada berdistribusi normal yang sesuai syarat normalitas dimana jika nilai $p>0,05$ maka dapat disimpulkan bahwa data berdistribusi secara normal. Uji normalitas dalam penelitian ini menggunakan uji kolmogrov-smirnov. Data dikatakan terdistribusi secara normal apabila nilai signifikasi p-value dari Kolmogrov Smirnov test $>0,05$ atau tidak signifikan bila nilai p<0,05 [10]. Dari pengujian normalitas pada tabel diatas terlihat bahwa signifikasi sebesar 0,009 atau lebih kecil dari $\alpha(0,05)$. Hal ini berarti data residual tidak berdistribusi normal, sehingga dapat disimpulkan model regresi tidak memenuhi asumsi nilai normalitas. Dasar pengambilan keputusan yaitu jika probabilitas lebih besar dari 0,05 maka $\mathrm{H}_{0}$ diterima yang berarti variabel berdistribusi normal dan jika probabilitas kurang dari 0,05 maka $\mathrm{H}_{0}$ (Hipotesis) ditolak yang berarti variabel tidak berdistribusi normal.Data dari hasil uji viskositas daun talas senthe dengan beberapa konsentrasi krmudian dilakukan uji normalitas mrnggunakan uji One Sample Kolmogrov-Smirnov Test untuk membuat data berdistribusi normal. Data yang dihasilkan dapat dilihat pada tabel berikut :

Tabel III. Hasil Uji Normalitas dengan Menggunakan One Sample Kolmogrov-Smirnov Test

\begin{tabular}{llrr}
\hline & & VAR000 & \multicolumn{2}{c}{ VAR000 } \\
& & $\mathbf{0 1}$ & \multicolumn{1}{c}{$\mathbf{0 2}$} \\
\hline $\mathrm{N}$ & & 24 & 24 \\
Normal Parametersa,b & Mean & 4,5000 & 865,1667 \\
& Std. & 2,34057 & 48,56073 \\
& Deviation & & \\
Most Extreme & Absolut &, 114 &, 208 \\
Differences & Positif &, 114 &, 122 \\
& Negatif &,- 114 &,- 208 \\
& & & \\
Test Statistic & &, 114 &, 208 \\
Asymp. Sig. (2-tailed) & &, $200^{c, d}$ &, $009 c$ \\
\hline
\end{tabular}

\subsection{Hasil Uji Kruskall Wallis}

Uji Kruskall Wallisbertujuan untuk membuktikan ada tidaknya perbedaan yang signifikana terhadap beberapa kelompok perlakuan. Hasil pengujian menunjukan bahwa rata-rata tingkat penurunan viskositas pada beberapa kelompok pengujian menunjukan nilai Chi square sebesar 22,266 dengan nilai signifikansi sebesar 0,002. Nilai signifikansi yang lebih kecil dari 0,05 menunjukan adanya perbedaan penurunan viskositas terhadap beberapa kelompok perlakuan. Hal ini berarti Hipotesis terbukti. Artinya, terdapat perbedaan tingkat penurunann viskositas mukus terhadap beberapa kelompok perlakuan. Dapat disimpulkan bahwa paling tidak ada beberapa perbedaan jumlah limfosit antara dua kelompok.Dengan demikian pengujian dilanjutkan dengan uji Non parametik yaitu melaui uji Kruskall Wallis. Hasil pengujian diperoleh sebagai berikut : 
Tabel IV. Hasil Uji Non Parametik

\begin{tabular}{l|l}
\hline & Konsentrasi \\
\hline Kruskal-Wallis H & 22,266 \\
Df & 7 \\
Asymp. Sig. & 0.002 \\
\hline
\end{tabular}

Dari hasil uji independent samples t-test menunjukan bahwa terdapat perbedaan yanag bermakna antara kelompok kontrol negatif dengan konsentrasi $1,75 \%(\mathrm{p}=0,034)$ dan antara kelompok konsentrasi $2 \%$ dengan kontrol negatif $(\mathrm{p}=0,012)$. Hal ini juga dapat menjelaskan bahwa terdapat hubungan antara kelompok dengan konsentasi yang paling rendah sampai konsentrasi yang paling tinggi. Dari hasil yang diperoleh menunjukan bahwa terdapat peningkatan aktivitas mukolitik setlah diberikan ekstrak etanol daun talas senthe dengan beberapa konsentrasi yang berbeda.Setelah dilakukan uji Kruskall-Wallis dilanjutkan uji Post Hoc menggunakan uji independent samples t-test untuk mengetahui letak perbedaan antara ketiga kelompok perlakuan. Hasil uji post hoc disajikan sebagai berikut :

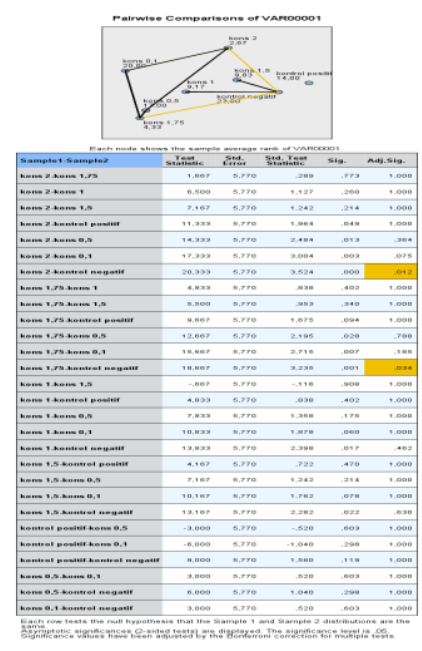

Gambar 1. Hasil uji post hoc 


\section{KESIMPULAN}

Hasil uji aktivitas mukolitik ekstrak etanol daun talas senthe menunjukan bahwa konsentrasi $0,1 \%$ sampai dengan konsentrasi $2 \%$ terdapat perbedaan kemampuan aktivitas mukolitik, dimana semakin tinggi konsentrasi viskositasnya semakin kecil.Hasil uji aktivitas mukolitik esktrak etanol daun talas senthe terhadap mukosa usus sapi menunjukan bahwa konsentrasi $1 \%, 1,5 \%, 1,75 \%$ dan $2 \%$ memberikan efek mukolitik yang sebanding dengan obat asetilsistein $0,1 \%$ sebagai pengencer dahak atau efektif dalam menurunkan viskositas larutan mukus.

\section{DAFTAR PUSTAKA}

[1] Wijayakusuma, H. M, et al. Tanaman Berkhasiat Obat di Indonesia Jilid I. 1994. Jakarta: Pustaka Kartini.

[2] BPOM RI, Obat Tradisional Mengandung Bahan Kimia Obat, 2015, Jakarta : Badan Pengawasan Obat dan Makanan Republik Indonesia.

[3] Srivastava, et al, Biological Activities Of Alocasia Macrorrhiza : a Review. Journal of Science, 2012, ISSN- 2277 - 1883.

[4] Robinson, J.M., \& Saputra, L, Buku Ajar Visual Nursing Medikal Bedah (Jilid 1), 2014, Jakarta : Binarupa Aksara

[5] Frandson .R.D, Darah dan cairan tubuh lainnya. edisi ke IV, 1993 Gadjah Mada University Press

[6] Leboe, D W., Ningsi, S., dan Annur, M. 2015. Uji Aktivatas Mukolitik Ekstrak Etanol Daun Tembelekan (Lanatana Camara Linn). Secara In Vitro. JF FIK UINAM. Vol.3 No. 1 : 22 26, 2015

[7] Departemen Kesehatan RI, Profil kesehatan Indonesia 2007, 2008, Jakarta : Depkes RI Jakarta.

[8] Azwar, Saifuddin, Metode Penelitian, 2011, Yogyakarta: Pustaka Pelajar.

[9] Widmann, Frances K. 1995. Tinjauan klinis atas hasil pemeriksaan laboratorium. Ed. 9, 1995, Penerjemah: Siti Boedina Kresno; Ganda Soebrata, J. Latu. Jakarta : EGC.

[10] Ghozali, Imam, “Aplikasi Analisis Multivariate Dengan Program SPSS, 2011, Semarang: Badan Penerbit Universitas Diponegoro. 